\title{
Konsep Dakwah Nir-Radikalisme Perspektif Syaikh Ali Mahfudz
}

\author{
Muhamad Agus Mushodiq ${ }^{1}$ \\ Institut Agama Islam Ma'arif NU Metro \\ Email: agusmushodiq92@gmail.com
}

\begin{abstract}
Abstrak: Tulisan ini bertujuan untuk mengeskplore konsep dakwah nir-
\end{abstract} radikalisme yang digagas oleh Ali Mahfudz. Meskipun secara eksplisit Ali Mahfudz tidak mengatakan di dalam magnum opusnya, bahwa konsep dakwahnya merujuk pada metode dakwah nir-radikalisme, penulis melihat banyak sekali indikasi yang mendukung konsep tersebut. Dalam melakukan penelitian, penulis menggunakan metode penelitian kualitatif pustaka dengan metode analisis konten. Dalam menganalisa data, penulis menggunakan indikator dakwah nir-radikalisme yang dirumuskan oleh Yusuf al-Qardhawi. Adapun hasil yang didapatkan dalam tulisan ini adalah (1). Konsep dakwah nir-radikalisme terejawantahkan melalui tiga konsepsi besar, yakni mauidzah (tadzkir dan qissah), isryad, dan khitabah yang di dalamnya terdapat repitisi penjelasan tentang pentingnya lemah lembut, bijaksana, lapang dada, sabar, dan selalu mengikuti cara dakwah rasul di dalam Alquran yang meliputi hikmah, mauidzah hasanah, dan perdebatan dengan cara yang paling baik, (2). Seorang pendakwah harus menyeimbangkan antara penggunaan wahyu dan akal, (3). Dalam hal yang bersifat khilafiyah, Ali Mahfudz hanya sekedar memaparkan saja, tanpa memaksa pembaca untuk fanatik terhadap satu paham, seperti hukum bagi seseorang yang tidak mendapatkan dakwah yang didasarkan pada paham Muktazilah, Asy'ariyah, dan al-Maturidiyah, (4). Diperbolehkannya penggunaan israiliyyat sebagai materi dakwah, penggunaan takwil dalam

${ }^{1}$ Penulis adalah dosen di Institut Agama Islam Ma'arif NU Metro yang sedang melanjutkan studi di Pascasarjana Program Doktoral di UIN Walisongo Semarang pada Prodi Studi Islam. 
memaknai ayat mutasyabihat, dan anjuran untuk merujuk para pakar teologi (mutakallimin) dalam berdakwah, (5). Kedinamisan beliau dalam berdakwah disinyalir disebabkan transformasi pengalaman keagamaan dari madzhab Syafi'i menuju madzhab Hanafi.

Kata kunci: Dakwah Ali Mahfudz; nir-radikalisme; mu'idzah; irsyad; khitabah.

Abtract: This paper aims to explore the concept of non-radicalism da'wah initiated by Ali Mahfudz. Although Ali Mahfudz did not explicitly say in his magnum opus, that the concept of da'wah refers to the method of nonradicalism da'wah, the author sees many indications that support the concept. In conducting research, the authors use qualitative-library research with content analysis methods. In analyzing the data, the writer uses the indicator of non-radicalism da'wah formulated by Yusuf alQaradawi. The results obtained in this paper are (1) the concept of nonradicalism da'wah embodied through three major conceptions, namely mauidzah (tadzkir and qissah), isryad, and khitabah in which there are explanatory explanations about the importance of gentleness, wisdom, grace, be patient, and always follow the way of the Prophet's da'wah in the Koran which includes wisdom, mauidzah hasanah, and debate in the best way, (2) a preacher must balance between the use of revelation and reason, (3) in matters that are khilafiyah, Ali Mahfudz just explained it, without forcing the reader to be fanatical about one understanding, such as the law for someone who does not get da'wah based on the Muktazilah, Asy'ariyah, and al-Maturidiyah understandings, (4) permitting the use of israiliyyat as $d a$ 'wah material, the use of takwil in interpreting the verse mutasyabihat, and the suggestion to refer the theologians (mutakallimin) in da'wah, (5) dynamism in his da'wah was allegedly caused by the transformation of religious experience from the Syafi'i school to the Hanafi school of thought. Keywords: Da'wah; Ali Mahfudz; Non-Radicalism ; Mu'idzah; Irsyad; Khitabah. 


\section{Pendahuluan}

Akhir-akhir ini, fenomena dakwah di Indonesia cukup mengkhawatirkan. Kecenderungan melakukan ujaran kebencian, ancaman terhadap pribadi seseorang, dan melakukan tindak kekerasan mewarnai aktifitas dakwah umat Islam. Belum lama ini, masyarakat Indonesia dihebohkan dengan adegan 'saling lapor' antara Permadi Arya atau lebih dikenal dengan Ustaz Abu Janda dan Ustaz Maaher At-Thuailibi. Permadi Arya melaporkan Maaher At-Thuailibi karena dianggap telah mengajak audiens untuk membunuhnya. ${ }^{2}$ Di sisi lain, Maaher At-Thuailibi melaporkan Permadi Arya karena telah mencemarkan nama baik dan memfitnahnya. ${ }^{3}$

Fakta lainnya yang masuk dalam ranah problematika dakwah juga menimpa Gus Muwafiq. Perdebatan dan permasalahan disebabkan karena materi dakwah yang disampaikan beliau, dianggap oleh segolongan orang telah merendahkan Nabi Muhammad saw. ${ }^{4}$ Terlepas dari unsur politik yang melatar belakangi pelaporan beliau oleh kelompok tertentu, apa yang dilakukan oleh Gus Muwafiq menjadi fenomena yang cukup menarik untuk ditelisik. Mengingat banyak sekali golongan dari kalangan ulama yang mengatakan bahwa penyampaian materi dakwah Gus Muwafiq yang belum

2 "Laporkan Balik Abu Janda, Ustaz Maheer: Dia yang Ketakutan," suara.com, December 1, 2019, https://www.suara.com/news/2019/12/01/185425/laporkan-balik-abujanda-ustaz-maheer-dia-yang-ketakutan.

3 "Dipolisikan, Ustaz Maaher: Saya Jelaskan Fikih Bukan Ajak Bunuh Abu Janda," accessed December 13, 2019, https://news.detik.com/berita/d4803770/dipolisikan-ustaz-maaher-saya-jelaskan-fikih-bukan-ajak-bunuh-abu-janda.

4 "Klarifikasi Gus Muwafiq Soal Masa Kecil Nabi Muhammad SAW, Budiman Sudjatmiko Minta Tak Diperpanjang - Tribunnews.Com," accessed December 13, 2019, https://www.tribunnews.com/nasional/2019/12/03/klarifikasi-gus-muwafiq-soal-masakecil-nabi-muhammad-saw-budiman-sudjatmiko-minta-tak-diperpanjang. 
banyak diketahui banyak orang, telah menyadarkan masyarakat untuk kembali mengkaji kitab kuning. Sedangkan kelompok lain mengatakan bahwa apa yang disampaikan oleh Gus Muwafiq terlalu berani dan melampaui batas dalam mendeskripsikan Nabi Muhammad saw.

Berdasarkan fenomena yang terjadi antara Abu Janda dan Maaher At-Thulaibi, disinyalir telah masuk pada ranah ekstrimisme dan radikalisme. Keduanya secara lantang di depan publik menyampaikan ujaran kebencian yang ekstrim. Hajir Tajiri mengatakan bahwa seorang pendakwah harus menghindari sikap ekstrim. Ekstrim di sini dimaknai dengan kefanatikan atau radikal dalam memahami suatu kelompok tertentu, sehingga terjadi saling menjatuhkan dan menjelek-jelekkan kelompok lain. Di sisi lain Yusuf al-Qardhawi juga mengisyaratkan adanya ciri-ciri ekstrim dalam berdakwah. Di antaranya adalah: (1) fanatik dan condong terhadap satu pendapat dengan mengabaikan bahkan tidak menghargai pendapat madzhab atau kelompok lain, (2) mewajibkan sesuatu padahal Allah SWT tidak mewajibkan hal tersebut, (3) menerapkan ajaran Islam dengan keras di tempat yang tidak seharusnya. Misalnya saja ada seseorang yang baru saja masuk Islam (muallaf) lalu dibebankan dengan sangat ketat hukumhukum Islam secara langsung, dan (4) mempraktikkan sikap keras dalam bergaul dan berdakwah. Di sisi lain Rasulullah di dalam salah satu haditsnya memerintahkan manusia untuk berdakwah dengan lemah lembut dan bijak (hikmah). ${ }^{5}$

5 UIN Sunan Gunung Djati, ed., Kajian Dakwah Multiperspektif: Teori, Metodologi, Problem, Dan Aplikasi, Cetakan pertama (Bandung: Kerja sama Fakultas Dakwah dan Komunikasi, Universitas Islam Negeri Sunan Gunung Djati dan PT Remaja Rosdakarya, 2014), 214. 
Jika ditelisik lebih dalam, permasalahan dakwah tersebut sejatinya sudah digambarkan dengan jelas oleh Syaikh Ali Mahfudz melalui dua magnum opusnya Hidayatul Mursyidin dan Fan Khitabah. Dalam kasus Gus Muwafiq misalnya, bisa jadi apa yang disampaikan memang terdapat di dalam riwayat atau kitab-kitab klasik. Akan tetapi kejelian dalam melihat kondisi audiens, -telebih saat ini munculnya media massa yang dapat menyebarkan materi dakwah dapat diakses secara massif oleh siapapunperlu untuk diperhatikan. Mengingat bahwa menurut Ali Mahdudz salah satu hal yang perlu diperhatikan dalam aktifitas dakwah adalah mengetahui kondisi audiens dan menjauhi berbicara kepada orang awam mengenai hal yang tidak dapat dipahami dan diterima sehingga akan menimbulkan salah paham. $^{6}$

Di dalam kajian sejarah ilmu dakwah, tidak bisa dipungkiri bahwa salah satu aspek penting yang menjadikan Islam tersebar di kawasan Arab adalah dakwah yang dilakukan oleh Nabi Muhammad saw. Menurut Samsul Munir Amin, dakwah adalah kegiatan yang dilakukan oleh da'i (pendakwah) secara sadar dalam rangka menyampaikan ajaran-ajaran agama Islam dengan strategi tertentu kepada orang lain dengan tujuan agar meteri-meteri yang disampaikan dapat diterima dan diamalkan baik dalam ruang lingkup kehidupan pribadi ataupun sosial. ${ }^{7}$ Adapun Quraish Shihab menjelaskan bahwa dakwah merupakan panggilan menuju keinsafan yang mengubah pribadi dan masyarakat menjadi lebih baik dan menanamkan ajaran-ajaran Islam di berbagai aspek kehidupan manusia, khususnya di era

${ }^{6}$ Ali Mahfudz, Hidayatul Mursyidin Ila Turuqi Al-Wa'dzi Wa Al-Khitabah (Qahirah: Dar I'tisam, 1979).

${ }^{7}$ Samsul Munir Amin, Sejarah dakwah, 2014, 3. 
modern yang lebih kompleks. Akan tetapi metode dakwah yang penuh dengan kasih sayang dan penuh toleransi sangat urgen untuk dilakukan.

Dalam sejarahnya, Nabi Muhammad melakukan dakwah kepada para keluarga terdekatnya terlebih dahulu mengenai pelarangan penyembahan terhadap berhala, seruan tauhid atau mengesakan Tuhan, dan kewajiban beribadah kepada Allah SWT. Selain itu, perjuangan dakwah Nabi Muhammad dapat dikelompokkan menjadi dua periode, yakni periode Mekkah dan periode Madinah. Adapun di Mekkah, Nabi Muhammad menggunakan dua srategi dakwah. Pertama adalah dakwah secara sembunyi-sembunyi yang berlangsung selama tiga Tahun. Sedangkan orang-orang yang didakwahi masih sangat terbatas, yakni para keluarga dan para sahabat nabi. Adapun strategi kedua adalah terang-terangan. Nabi Muhammad diperintahkan Allah untuk melakukan dakwah secara terangterangan kepada segenap warga Mekkah dengan turunnya ayat ke- 94 Surat al-Hijr dan ayat ke- 214-216 Surat Asy-Syu'ara. Adapun periode kedua, adalah periode Madinah. Nabi Muhammad melakukan dakwah di Madinah ketika beliau hijrah ke daerah tersebut. Adapun materi dakwahnya berkaitan dengan kemasyarakatan dan kenegaraan. ${ }^{8}$

Setelah Nabi Muhammad saw wafat, perjuangan dakwah menyebarkan Islam dan memperbaiki akhlak masyarakat dilanjutkan oleh Khulafau Rasyidin. Jika pada masa Nabi Muhammad hasil dari dakwah adalah mengislamkan masyarakat yang berada di daerah Jazirah Arab, maka pada masa Khulafau Rasyidin Islam tersebar lebih luas lagi, yakni di daerah Afrika, Persia, Bizantium dan India. Setelah itu, periodisasi sejarah diteruskan oleh generasi-generasi selanjutnya, seperti yang dilakukan oleh

\footnotetext{
${ }^{8}$ Amin, 14.
} 
para khalifah dinasti Umayyah, Dinasti Abassiyah, dan dinasti lain hingga saat ini. Metode dakwah yang dilakukan oleh Nabi Muhammad paling tidak telah tertuang di dalam ayat Alquran yang mengandung konsep hikmah (kebijaksanaan), mauidzah hasanah (nasehat yang baik), dan mujadalah bi ahsani turuq (perdebatan dengan cara yang paling baik).

Adapun ilmu dakwah atau konsepsi dakwah sebagai salah satu bidang ilmu terbentuk melalui proses yang cukup panjang sebagaimana ilmu-ilmu lainnya. Secara garis besar jika dilihat melalui periodisasinya adalah (1) tahap konvensional. Pada tahap konvensional ilmu dakwah dimulai dengan upaya pengumpulan manuskrip dan naskah khutbah Rasulullah saw oleh Jabir ibn Abdullah pada tahun 697 M. Kumpulan khutbah tersebut dikenal dengan Shahifah Jabir ibn Abdullah dan disusul dengan karya Shahifah Hammam ibn Munabbih atau dikenal dengan istilah Shahifah Abu Hurairah yang berisikan sekitar 138 hadits. Akan tetapi menurut Ahmad Anas, jika kumpulan surat Rasulullah saw kepada para raja yang dihimpun oleh 'Amr bin Hamz dapat dijadikan sebagai literatur dakwah, maka kumpulan surat yang dicetak sekarang dengan judul I'lam al-Sailin yang ditulis oleh Ibn Tulun dapat disebut sebagai literatur pertama dalam ilmu dakwah konvensional. Di dalam perkembangannya juga muncul tokoh-tokoh Islam yang megkaji tentang dakwah meskipun secara implisit. Salah satunya adalah Imam al-Ghazali melalui magnum opusnya Ihya 'Ulumu ad-Din yang di dalamnya terdapat kajian amar ma'ruf nahi munkar. Dalam melakukan klasifikasi Ilmu, al-Ghazali juga memasukkan dakwah sebagai salah satu disiplin ilmu yang masuk dalam pembahasan jihad yang masuk dalam klasifikasi ilmu Fardu 'Ain. Setelah al-Ghazali, pada Tahun 1283 muncul tokoh yang bernama Quthb al-Din al-Syrazi 
memasukkan dakwah sebagai ilmu 'ilmu al-muhadarat sebagai ilmu yang menjadi cabang keilmuan Agama. (2) Tahap sistematis, tahap ini ditenggarai sebagai masa transisi antara masa konvensial dan imiah. Kajian secara spesifik mengenai dakwah telah dilakukan oleh para cendekiawan muslim. Kajian-kajian khusus seperti seminar dan diskusi sudah dilaksanakan. Bahkan beberapa lembaga akademik yang mengkaji tentang dakwah seperti Dar al-Da'wah wa al-Irsyad di Mesir Kairo pada tahun 1912 sudah dibangun untuk menghadang kristenisasi, ${ }^{9}$ tetapi ditutup pasca perang dunia II. (3) Tahap Ilmiah. Pada tahap inilah kajian dakwah memiliki objek kajian, memiliki metode, dan disusun dengan sangat sistematis. Sumber literatur dakwah pada saat ini sudah mulai dapat dipertanggungjawabkan secara ilmiah dan historis (bukan ahistoris). Bahkan perguruan tinggi Islam seperti Al-Azhar Kairo membuat program studi dakwah yang digagas oleh Syaikh Ali Mahfudz sebagai tokoh yang dikaji di dalam tulisan ini. ${ }^{10}$

Kajian mengenai konsep dakwah Ali Mahfudz secara spesifik belum dilakukan leh peneliti lain, akan tetapi penukilan pendapat dari Syaikh Ali Mahfudz telah banyak dilakukan dalam mendefiniskan dakwah. Di antara tulisan yang menyinggung pendapat Syaikh Ali Mahfudz adalah tulisan dengan judul "Dakwah dan Pengembangan Masyarakat" yang ditulis oleh Masmuddin. Di dalam tulisannya tersebut, Masmuddin menyimpulkan bahwa dakwah merupakan suatu upaya yang dilakukan untuk menunjukkan manusia ke jalan yang benar dan diridhai Allah SWT.

${ }^{9}$ H. Moh Ali Aziz, Ilmu Dakwah (Jakarta: Kencana, 2004), 83.

${ }^{10}$ Ahmad Anas and Abu Fina, Paradigma dakwah kontemporer: aplikasi teoritis dan praktis dakwah sebagai solusi problematika kekinian (Semarang: Pustaka Rizki Putra, 2006), 22. 
Selain itu dakwah saat ini tidak hanya diproyeksinya untuk melakukan amar ma'ruf nahi munkar saja, tetapi juga upaya untuk mengajak manusia mendapatkan kemaslahatan dari bidang yang mereka geluti. Selain itu dakwah dan pengembangan masyarakat juga tidak mungkin dipisahkan, karena sasaran dakwah adalah manusia itu sendiri. ${ }^{11}$ Tulisan lain yang relevan ditulis oleh Roidah dengan judul "Definisi Dakwah Islamiyyah Ditinjau dari Perspektif Konsep Komunikasi Konvergensi Katherine Miller". Di dalam tulisannya tersebut, Rosidah menyimpulkan bahwa terdapat keselarasan antara metode dakwah yang dikemukakan oleh Alquran dan para ahli Islam dengan teori komunikasi konvergensi yang dirumuskan oleh Miller. Titik kesamaan terletak pada sifat fleskibel dan elastis dakwah dengan berbagai macam kondisi dan situasi tanpa menghilangkan esensi dari tujuan dakwah itu sendiri. ${ }^{12}$

Berdasarkan hal tersebut, dalam artikel ini, penulis melakukan eksplorasi terhadap konsep dakwah yang dirumuskan oleh Ali Mahfudz yang disinyalir mengandung konsep dakwah nir-radikalisme. Pengkajian tersebut sangat penting dilakukan karena berdasarkan observasi sekilas mengenai karya-karya beliau, penulis mendapati konsep dakwah yang sangat menekankan rahmah kasih saying, hulm (lemah lebut) dan lain sebagainya yang sangat jauh dari ideologi radikalisme dan ekstrimisme. Berbeda dengan fenomena dakwah saat ini yang lekat dengan ujaran

\footnotetext{
11 "DAKWAH DAN PENGEMBANGAN MASYARAKAT," accessed December 13, 2019, http://altajdidstain.blogspot.com/2011/02/dakwah-danpengembangan-masyarakat.html.

12 Rosidah Rosidah, "DEFINISI DAKWAH ISLAMIYYAH DITINJAU DARI PERSPEKTIF KONSEP KOMUNIKASI KONVERGENSI KATHERINE MILLER,” QATHRUNÂ 2, no. 02 (December 10, 2015): 155-78.
} 
kebencian, mengolok-olok kelompok lain, dan tindakan-tindakan tidak terpuji lainnya.

\section{Metode Penelitian}

Dalam mengkaji kosep dakwah nir-radikalisme ala Ali Mahfudz, penulis menggunakan metode peneliian kualitatif pustaka. ${ }^{13}$ Sumber data primer dalam tulisan ini adalah Kitab Hidayatul Mursyidin dan Fan Khitabah karya Ali Mahfudz. Sedangkan sumber primer yang digunakan adalah buku dan artikel jurnal yang terkait dengan objek pembahasan. Dalam melakukan penelusuran data, penulis menggunakan teknik simak, dengan teknik lanjutan teknik catat. Teknik tersebut sangat sesuai dengan sumber data kepustakaan. ${ }^{14}$ Adapun metode analisis data yang digunakan adalah analisi konten (content analysis). Dalam menentukan konsep dakwah nir radikalisme yang digagas oleh Ali Mahfudz, peneliti menggunakan indicator-indikator yang disampaikan oleh Yusuf al-Qardawi sebagaimana yang telah dijelaskan di pendahuluan. Indicator yang dimaksud adalah: (1) fanatik dan condong terhadap satu pendapat dengan mengabaikan bahkan tidak menghargai pendapat madzhab atau kelompok lain, (2) mewajibkan sesuatu padahal Allah SWT tidak mewajibkan hal tersebut, (3) menerapkan ajaran Islam dengan keras di tempat yang tidak seharusnya. Misalnya saja ada seseorang yang baru saja masuk Islam (muallaf) lalu dibebankan dengan sangat ketat hukum-hukum Islam secara langsung, dan (4) mempraktikkan sikap keras dalam bergaul dan berdakwah. Di sisi lain Rasulullah di dalam salah satu haditsnya

13 J.R. Raco, Metode Penelitian Kualitatif (Jakarta: PT Grasindo, 2010), 34.

14 M. S Mahsun, Metode penelitian bahasa: tahapan strategi, metode dan tekniknya (Jakarta: PT RajaGrafindo Persada, 2005), 24. 
memerintahkan manusia untuk berdakwah dengan lemah lembut dan bijak (hikmah).

\section{Pembahasan}

\section{Biografi ‘Ali Mahfudz}

Ali Mahfudz (1880-1942 M) dan keluarganya tinggal di daerah Thantha Barat. Keluarganya merupakan keluarga yang sangat baik karena nasabnya tersambung hingga Hasan ibn Aly ra. Di desa tersebut Mahfudz menghapal Alquran dan menguasai matan-matan hadits. Pada tahun 1306 H. dia melanjutkan studi di al-Jami' (masjid) al-Ahmady yang terletak di Thantha. Di sana dia mendalami ilmu Tajwid Alquran dengan beberapa ahli fiqih. Dia juga melakukan talaqi ilmu dengan berbagai grand syeikh, seperti Syaikh 'Abdu ar-Rahman ad-Dimaty, as-Syaikh Muhammad AsySyabiny al-Kabir, Syaikh 'Aly al-Manufa, dan Syaikh Qutb Bakr. Mahfudz dikenal sebagai murid yang sangat rajin dan bersungguh-sungguh. Ketika dia belajar di al-Jami' al-Ahmady selama kurang lebih sepuluh tahun telah tampak pada dirinya kejeniusan dan keunggulan di antara para temantemannya. ${ }^{15}$

Oleh karena gurunya Syaikh ad-Dimaty melihat kejeniusan pada diri Mahfudz, maka dia berpendapat bahwa kejeniusan tersebut harus dimanfaatkan oleh Universitas al-Azhar as-Syarif. Maka Mahfudz pun mencari ilmu di al-Azhar Mesir pada tahun 1317 H. Di kampus tersebut dia cenderung mempelajari, mendalami, dan mengamalkan fiqih madzhab Hanafiah yang mana dia dulunya penganut madzhab as-Syafi'i. Dia berguru dengan berbagai syaikh, di antaranya adalah Syaikh Muhammad Halby, Syaikh Bakr as-Sadafy, Syaikh Ahmad Abu Khutwah, Syaikh Muhammad

${ }^{15}$ Mahfudz, Hidayatul Mursyidin Ila Turuqi Al-Wa'dzi Wa Al-Khitabah, 8. 
Bakhit, dan Profesor Muhammad 'Abduh. Adapun pada tahun 1324 H yang bertepatan dengan tahun 1907 M, dia mendapatkan Ijazah Ilmiah, lalu dia disibukkan dengan mengajar. ${ }^{16}$

Ketika dia dimasukkan ke dalam kepengurusan (nidzam) al-Azhar pada tahun 1911, dia melanjutkan studi hingga mencapai Qism 'Aly. Adapun pada tahun 1918 didirikan qism (jurusan) al-Wa'dz wa al-Irsyad, adapun orang yang pertama melakukan pendirian (pelopor) jurusuan tersebut adalah Ali Mahfudz. Ketika dia masuk dalam jurusan ini (sebagai pengajar) dia menemukan concern studinya. Dia sangat bersungguhsungguh di dalamnya. Sehingga di tangan beliau lahirlah para da'i-da'i hebat dari kalangan al-Azhar. Sumbangsih Ali Mahfudz dalam menjadikan dakwah sebagai ilmu akademis yang diakui, dilanjutkan oleh al-Ghazali pada Tahun 1954 dengan menulis buku Maukibi al-Du'ah dan disempurnakan menjadi Dirasah fi Da'wah wa Du'ah pada tahun 1961. Adapun pada tahun 1962 Abu Bakar Zahri menulis buku ad-Dakwah ila Islam sebagai buku rujukan ilmu dakwah pada saat itu. ${ }^{17}$

Adapun pada tahun $1356 \mathrm{H}$ yang bertepatan dengan $1938 \mathrm{M}$, dia menjadi delegasi dari al-Azhar untuk pergi ke penjuru daerah Hijaz melaksanakan ibadah haji. ${ }^{18}$ Pada bulan Mei 1939 M Dewan Grand Syaikh (Hai'ah Kibar al-Ulama') Al-Azhar memperhitungkan keilmuan, keutamaan, dan kelebihan-kelebihan lain dari Ali Mahfudz, sehingga ditetapkan bahwa dia salah satu dari anggota Grand Syaikh al-Azhar. Pada

${ }^{16}$ Mahfudz, 8.

17 Ahidul Asror, Paradigma dakwah konsepsi dan dasar pengembangan ilmu (Yogyakarta: LKiS Yogyakarta, 2018), 62, http://digilib.iain-jember.ac.id/253/.

${ }^{18}$ Mahfudz, Hidayatul Mursyidin Ila Turuqi Al-Wa'dzi Wa Al-Khitabah, 7. 
tahun 1941, beliau diberi pakaian mewah khusus (kiswah) penghormatan akademis.

Adapun rutinitas dari Ali Mahfudz di setiap minggunya dia melakukan safari dakwah dari masjid ke masjid dengan tujuan agar masyarakat di sekitarnya dapat berpegang teguh dengan tali (Agama) Allah dengan kuat. Dia dikenal para jamaahnya memiliki kekuatan dan keterampilan penjelasan sangat baik dengan menggunakan uslub (stilistika) yang sangat indah dan ungkapan-ungkapan yang memukau. Sehingga dia juga menuliskan metode ceramah dengan berbagai karya tulisnya seperti Sabilu al-Hikmah fi al-Wa'dz wa al-Khitabah, Hidayatu al-Mursyidin ila Turuqi al-Wa'dzi wa al-Khitabah. Buku yang terakhir merupakan buku pertama kali yang membahas tentang metode khitabah yang dibukukan secara sistematis dan dijadikan rujukan utama para akademisi. Selain di masjid-masjid perkotaan, beliau juga melakukan kajian atau ceramah di pelosok-pelosok desa yang terpencil jauh dari sentuhan ilmu pengetahuan, khususnya tentang keagamaan. Beliau menginfakkan hartanya untuk mengunjungi desa-desa tersebut dalam rangka menghabiskan waktu liburan musim panas dengan mengisi ceramah di berbagai negara. Disinyalir kumpulan khutbahnya yang disampaikan di tempat-tempat terpencil sudah dikumpulkan dan menghasilkan 1000 materi ceramah. ${ }^{19}$

Beliau juga dikenal sebagai penceramah yang memerangi bid'ah dan khurafat. Beliau memandang bahwa bid'ah dan khurafat telah merasuki jiwa masyarakat sehingga membuat mereka jauh dari agama yag lurus. Untuk itu beliau melakukan "jihad" akademis dan mengingatkan masyarakat akan kebaikan-kebaikan agama yang telah ditetapkan syariat

${ }^{19}$ Mahfudz, 9. 
dan menjelaskan keburukan-keburukan bid'ah. Sehingga beliau menuliskan materi bahaya bidah dalam bukunya "al-Ibda' fi Mudhar al-Ibtida'. ${ }^{20}$

Selain melakukan dakwah, beliau juga mendirikan organisasi Islam (jamiyyah islamiyah). Beliau meyakini bahwa organisasi akan mempermudah menyebarkan nilai-nilai Islam di kalangan umat. Dengan keyakinan tersebut beliau mendirikan berbagai organisasi Islam, di antaranya adalah Jamiyyah Makarimi al-Akhlaq al-Islamiyyah dan Jamiyyah al-Hidayah al-Islamiyyah, Jamiyyah Tahfid al-Quran bi alAbbasiyyah, Jamiyyah ar-Raddu 'ala Mubsyirin, dan Jamiyyah Nasyr alFadail wa al-Adab al-Islamiyyah. Selain melakukan ceramah dan mendirikan organisasi yang bersifat umum tersebut Ali Mahfudz juga berkecimpung di organisasi Islam yang bersifat eksklusif terdiri dari para ulama besar. Seperti organisasi At-Tabaqah ar-Raqiyyah. Di organisasi tersebut Ali Mahfudz bersama para tokoh lain seperti Dr. Salim Handawi, Dr. Sulaiman 'Azmi Basya, Dr. 'Abd Aziz Ismail Basya melakukan penafsiran Alquran di malam tertentu di setiap minggunya.

Selain itu, beliau juga seringkali melakukan kajian keagamaan atau ceramah keagamaan di radio di setiap bulannya hingga beliau meninggal dunia. Kebiasaan beliau lainnya adalah melakukan kajian keagamaan di masjid al-Azhar setelah shalat Ashar di setiap hari bulan Ramadhan.

Adapun magnum opus dari Ali Mahfudz adalah (1) al-Akhlaq, buku yang diajarkan di Ma'had Ibtidai al-Azhar, (2) Sabilu al-Hikmati fi alWa'dzi wa al-Khitabati, (3) Hidayatu al-Mursyidin ila Turuqi al-Wadz wa al-Khitabah, sebagai buku yang diajarkan di Fakultas Ushuluddin al-Azhar, (4) al-Ibda fi Mudhar al-Ibtida' yang juga sebagai buku ajar di Fakultas 
Ushuluddin, (5) al-Khitabah (yang belum dicetak). Akan tetapi untuk buku ini peneliti berasumsi bahwa saat ini buku tersebut telah dicetak dengan judul Faanu al-Khitabah. ${ }^{21}$

\section{Konsep Dakwah Nir-Radikalisme Menurut Ali Mahfudz}

Menurut Ali Mahfudz makna dakwah secara bahasa adalah /ad-du'a ila syainn bima'na al-hatssu 'ala qasdihi/ 'mengajak atau menyeru kepada suatu hal, atau memotivasi, mengajak, menyeru sesuai dengan tujuan yang ingin dicapai'. Adapun secara terminlogi, dakwah adalah menyeru manusia untuk menuju kepada kebaikan dan petunjuk, memerintahkan kepada kebaikan dan melarang perbuatan keburukan (munkar) agar manusia berhasil mendapatkan kebahagiaan kehidupan dunia dan akhirat.

Menurut Ali Mahfudz terdapat tiga macam dakwah: (1) Seruan atau dakwah dari kalangan umat Nabi Muhammad kepada umat-umat lain untuk menuju ke agama Islam. Merupakan suatu kewajiban bagi umat Nabi Muhammad melakukan dakwah atau ajakan kepada umat manusia lain untuk menuju ke Agama Islam, jika mereka merespon dengan masuk ke dalam agama Islam, maka umat Nabi Muhammad juga harus menyuruh mereka melakukan perbuatan baik dan melarang mereka untuk melakukan perbuatan buruk atau munkar. (2) Seruan atau dakwah yang dilakukan antara umat muslim dengan umat muslim lainnya. Dalam hal ini mereka harus saling menasehati, saling menyeru untuk melakukan kebaikan dan saling melarang untuk hal keburukan. (3) Dakwah antara satu individu dengan individu lainnya. Jika seorang muslim melihat saudara muslim

${ }^{21}$ Mahfudz, 12. 


\section{WARDAH Jurnal Dakwah dan Kemasyarakatan}

lainnya melakukan keburukan, maka dia harus berdakwah dengan mencegahnya melakukan keburukan dan memintanya untuk melakukan kebaikan. $^{22}$

\section{a. Tingkatan Dakwah}

Menurut Ali Mahfudz dakwah atau seruan untuk menuju kepada Allah ada beberapa tingkatan. Tingkatan pertama adalah dakwah para nabi. Adapun ciri-ciri dakwah para nabi adalah (1) Berdakwah menggunakan argumen yang kuat dan jelas untuk permulaan, adapun selanjutnya dakwah menggunakan pedang untuk melindung diri dan mendukung kebenaran. Mereka tidak memaksa orang-orang lain untuk masuk ke dalam agama atau ajaran yang mereka bawa (baca: Islam), (2) Mereka merupakan pelopor dakwah di dunia, sehingga para ulama setelahnya membangun strategi dakwah berdasarkan apa yang telah dilakukan oleh para nabi. (3) Jiwa mereka kuat, dan ruh mereka lebih suci dan bersih sehingga pengaruh dakwah mereka sangat lah kuat, (4) Jiwa para nabi memiliki dua kelebihan, pertama jiwa mereka memang sempurna dan jiwa mereka membuat lainnya sempurna. Sehingga kekuatan mereka untuk berdakwah menuju kepada Allah lebih kuat dari hamba Allah lainnya. Untuk itu derajat mereka lebih tinggi dari pada lainnya. Adapun tingkatan kedua dan ketiga adalah dakwah para ulama dan raja (pemimpin negara) yang menggantikan dan mewariskan para nabi. Para nabi memiliki dua sifat, ilmu dan kekuatan. Ulama meupakan perwakilan dari para nabi dari segi ilmu sedangkan raja

${ }^{22}$ Mahfudz, 18. 
atau pemimpin negara yang adil merupakan perwakilan para nabi dari segi kekuatan. $^{23}$

Dengan demikian dapat disimpulkan bahwa derajat tertinggi setelah para nabi dalam hal dakwah adalah para ulama'. Ulama' juga terbagi menjadi tiga macam, pertama adalah ulama' hukama', yakni para ulama yang bijaksana yang berkaitan dengan akhlak. Kedua ulama' ushul, yakni para ulama yang concern pada sifat-sifat Allah atau teolog, dan ketiga ulama' fuqaha' yang concern di bidang hukum-hukum Allah. Tugas para ulama adalah membenahi akhlak, dan di sisi lain mereka juga harus berakhlak mulia, berbuat zuhud, mengetahui sifat Allah dan wujudnya, mengetahui cara mengeluarkan atau mengistinbathkan hukum, sehingga akan diketahui mana haram dan mana halal yang dilandaskan pada Alquran dan As-Sunnah. Sedangkan raja atau pemimpin yang adil dapat berdakwah menggunakan "pedang" dalam dua bentuk, (1) Memerangi orang-orang kafir yang membangkang, dan (2) Memerangi orang-orang yang murtad dari jalan Allah SWT.

Dengan demikian konsep dasar dari dakwah untuk menuju kepada Allah adalah ketaatan kepada Allah, mengesakannya, dan membimbing makhluk atau manusia lainnya menuju jalan yang benar merupakan tugas dari para rasul, para ulama, dan para pemimpin. ${ }^{24}$ Adapun seorang pendakwah atau da'i merupakan khalifat (perwakilan) Allah di muka bumi, khalifah para rasulnya, khalifah kitab-Nya dalam menyampaikan syariatsyariat-Nya, dalam menjelaskan sunnah para nabinya, dan menjelaskan akhlaknya yang indah menyerupai Alquran, dan sebagainya.

\footnotetext{
${ }^{23}$ Mahfudz, 15.

${ }^{24}$ Mahfudz, 15.
} 
Ali Mahfudz juga menekankan bahwa dakwah merupakan tarbiyah (pendidikan). Sedangkan tarbiyah yang bermanfaat berbentuk suatu amalan sehingga menjadi pedoman dan tuntunan (uswah) yang baik. ${ }^{25}$

Beliau juga menjelaskan bahwa dakwah merupakan upaya untuk menyebarkan hidayah islamiyah dengan membenahi akidah, perbuatan yang sesuai dengan ajaran Alquran dan as-Sunnah, mendidik moralitas, memperkuat persaudaraan antara umat Islam, dan memerangi ateisme, dan syubhat-syubhat dalam beragama. Untuk mencapai itu semua, dibutuhkan media-media berikut ini (1) melakukan dakwah sesuai dengan kemampuan (pekerjaan dan lain sebagainya), (2) menyebarkan para da'i, mursyid yang pandai dalam menasehati dari kalangan muslim (missionaries) ke desa-desa dan tempat-tempat terpencil, (3) menyebarkan dan mempublikasi bukubuku dan surat keagamaan yang terkandung di dalamnya ilmu dasar atau pokok Islam dan cabang-cabangnya, fadilah dan adab yang terkandung di dalam Alquran dan al-Sunnah dan rahasia-rahaisa syariah yang terkandung di dalamnya (maqasid asy-syari'ah). (4) menyampaikan khutbah, pengajian agama terbuka di kalangan masyarakat umum dan menyebarkan makalahmakalah seperti bulletin agama untuk mereka, (5) membuat jurnal atau majalah Islam dengan menggunakan bahasa Arab di seluruh penjuru dunia, khususnya di daerah-daerah Islam, (6) membenahi metode dan startegi khutbah minbariyah dan mengajarkan cara menasehati dan membimbing di masjid-masjid (7) melakukan usaha kerjasama dengan pemerintahan dan negara-negara Islam khususnya di sekolahan-sekolahan negara tersebut untuk mengajarkan materi-materi keagamaan dan pendidikan Islam. ${ }^{26}$

\footnotetext{
${ }^{25}$ Mahfudz, 16.

${ }^{26}$ Mahfudz, 16.
} 


\section{b. Kebutuhan manusia terhadap dakwah}

Menurut Ali Mahfudz, Allah SWT memang telah menganugerahkan manusia dengan ciptaan yang sempurna, dan memuliakannya dengan diberikan pemikiran dan akal sehingga dapat membedakan antara baik dan buruk, antara hak dan batil. Akan tetapi akal manusia tidak bebas atau tidak bisa dengan sendirinya mengetahui kebaikan-kebaikan perkara dunia dan akhirat. Dia (akal) juga tidak mampu menunjukkan dirinya sendiri kepada upaya pembedaan antara yang baik dan yang buruk, dia juga tidak mampu mengetahui hakikat dari suatu hal dengan sendirinya. Kadang-kadang akal manusia juga cenderung memerintahkan pemiliknya untuk melakukan hal yang batil daripada hal yang hak, berpaling dari kebaikan dan menuju kepada keburukan, melakukan hal yang buruk di bawah baju kebaikan, Jika akal manusia terbiasa memikirkan hal yang baik dan buruk, maka pemilik akal tersebut mampu untuk mengalahkan syahwat, marah dan hasad yang ada pada dirinya. Adapun jika akal luput dari memikirkan dari bahaya syahwat, marah, dan dengki, maka dia tidak akan selamat dari kubangan perpecahan dan perselisihan.

Oleh karena akal manusia sangat terbatas untuk mengetahui hakikat kebaikan-kebaikan di dalam kehidupan, dan sangat lemah dalam mencari hakikat sesuatu, maka dia membutuhkan petunjuk orang-orang muslih, dan para da'i yang memberikan nasehar-nasehat untuk mengajarkan mereka cara membenahi kehidupan mereka, mengajak mereka untuk menuju kebaikan, mencegah mereka untuk jatuh di dalam jurang keburukan, membebaskan akal mereka dari hawa nafsu dan syahwat, membersihkan, mensucikan jiwa mereka dari noda-noda jiwa, dan memberitahu mereka 
cara terbebas dari fitnah. Orang-orang yang mampu melakukan itu semua tidak lain dan tidak bukan adalah para rasul, nabi dan para pewaris mereka.

Sebagaimana yang telah diketahui sebelumnya bahwa kebutuhan melakukan dakwah sangtalh urgent dan besar. Mengajak dan menyuruh kepada hal yang baik dan mencegah melakukan keburukan merupakan poros agama yang paling agung. Ali Mahfudz mengatakan bahwa melakukan dakwah merupakan kewajiban bagi umat Islam, dia mengutip salah satu ayat di dalam Alquran yang artinya :

dan hendaklah ada di antara kamu segolongan umat yang menyeru kepada kebajikan, menyuruh kepada yang ma'ruf dan mencegah dari yang munkar; merekalah orang-orang yang beruntung.

Menurut Ali Mahfudz ayat di atas menunjukan bahwa umat Islam wajib mendirikan suatu kelompok atau organisasi yang melakukan pendalaman (tafaqquh) dalam ilmu agama dan memiliki tugas melakukan dakwah untuk menyeru manusia melakukan kebaikan dan mencegah mereka melakukan keburukan, demi menjaga syariat dari orang-orang yang ingin melanggarnya, dan menjadi penjaga dari hukum-hukum yang ada di dalamnya dari serangan orang-orang yang telah dikuasai oleh syahwat dan kosong dari aturan hukum-hukum tersebut. Mukhatab atau lawan bicara dari ayat di atas adalah seluruh umat muslim yang harus memilih di antara mereka yang dapat melakukan tugas tersebut dengan baik. Menurut Ali Mahfudz kewajiban di sini diperuntuhkan untuk dua sisi. Sisi pertama adalah seluruh umat Islam harus melakukan dakwah, dan sisi kedua adalah orang-orang yang telah dipilih dalam suatu kelompok atau organisasi yang 
diberi tugas melakukan dakwah, baik dakwah untuk menyeru kepada perbaikan kehidupan dunia ataupun kehidupan akhirat. ${ }^{27}$

Dalam menjelaskan kewajiban dakwah, Ali Mahfudz juga mengutip hadits yang sebagian redaksinya adalah /man ra'a minkum mnkaran falyugayyiru biyadihi, fa in lam yastati' fa bilisanihi, fa in lam yastati' fa biqalbihi, wa zalika ad'afu iman $/{ }^{28}$ Dalam hadits ini, Ali Mahfudz membedakan antara nahyu dan tagyiru terhadap kemunkaran. Nahyu almunkar dilakukan sebelum pelaku melakukan hal yang munkar, sedangkan tagyir mengindikasikan bahwa pelaku (objek yang didakwahi) telah melakukan kemunkaran. Sehingga dalam mengubah perilaku buruk menjadi baik terdapat tiga tingkatan, yakni dengan tangan atau kekuasaan, dengan lisan, dan dengan hati. Menurut Ali Mahfudz berdakwah dengan hati maksudnya adalah tidak ridha atau tidak menyukai kemunkaran yang dilakukan seseorang. Berdakwah dengan hati merupakan tingkatan paling rendah, karena sangat sedikit memberikan kebermanfaatan dalam perubahan. ${ }^{29}$

\section{c. Hukum bagi orang yang tidak mendapatkan dakwah}

Menurut Ali Mahaudz, orang-orang yang tidak mendapatkan dakwah Islam, dapat dipandang dari tiga perspektif. Pertama jika dilihat melalui sudut pandang Asy'ariyah. Seseorang yang belum mendapatkan dakwah atau dakwah Islam belum sampai padanya maka tidak masuk kategori taklif atau orang yang dibebani dengan syariat. Prinsip ini dikaitkan dengan para ahli fatrah, yakni orang-orang di masa tenggang tidak diutusnya rasul. Para

\footnotetext{
${ }^{27}$ Mahfudz, 20.

${ }^{28}$ Mahfudz, 22.

${ }^{29}$ Mahfudz, 22.
} 
ahli fatrah yang di dalamnya adalah para pendahulu sahabat dan orang tua nabi, selamat dari siksa meskipun di antara mereka ada yang menyembah berhala dan lain sebagainya. Meskipun ada hadits yang menyatakan bahwa ahli fatrah masuk neraka seperti Umru'ul Qays, tetapi hadist tersebut merupakan hadits ahad yang memiliki substansi berbeda dengan ayat Alquran Iwa ma kunna muazzibina hatta nab'atsa rasula/. Dengan demikian Madzhab Asy'ariyah menyepakati bahwa syarat bagi mukallaf atau orang taklif yang dibebani dengan pengamalan syariat adalah sampainya dakwah Islam kepada dirinya. Sehingga mengetahui Allah itu harus didasarkan pada hukum syariat, penentuan baik dan buruk harus didasarkan pada syariat juga. Kelompok kedua adalah Madzhab Muktazilah yang mengatakan bahwa hukum itu didasarkan pada akal bukan pada syariat, syariat adalah penguat dari akal. Kaum Muktazilah meyakini bahwa suatu itu baik jika akal menerima bahwa hal tersebut baik, sedangkan sesuatu itu buruk jika akal mengatakan bahwa sesuatu itu buruk. Berbeda dengan penganut Asy'ariyah yang meyakini bahwa baik buruk itu ditentukan oleh syara'. Sedangkan Al-Maturidiyah lebih berada di tengah, kelompok ini berada di antara keduanya dengan mengatakan bahwa wajib mencari tahu atau mengetahui dengan akal ketika seseorang tidak menemukan hakikat sesuatu dari syara'.

\section{d. Kebiasan nabi dalam menyampaikan dakwah}

Telah disepakati bahwa materi dakwah para rasul untuk para kaumnya adalah tentang tauhid ulhiyyah, rububiyyah, keikhlasan ibadah, tunduk pada Allah, beriman kepada hari akhir, hari kebangkitan, dan balasan atas apa yang telah dilakukan di dunia, beriman kepada para rasul, suka dengan segala sesuatu yang merujuk pada ketaatan kepada Allah dan menjauhi 
segala kemaksiatan dan melanggar perintah-Nya. Selain itu para rasul juga kerap kali memotivasi umatnya untuk menghiasi jiwa dengan akhlak yang baik. Selain itu mereka juga membenahi dan "mengobati" penyakit sosial atau patologi sosial yang ada pada umat yang mereka bimbing.

Adapu Nabi Muhammad juga memiliki metode khusus dalam melakukan dakwah kepada umatnya. Prinsip pertama dalam dakwah rasul adalah menyampaikan materi dakwah dengan bukti yang jelas dan kuat. Dalam melakukan dakwah Nabi Muhammad menggunakan hujjah atau argumen yang jelas, empiris dan kuat, beliau tidak memberikan suatu argumen di luar kebiasaan bangsa Arab pada saat itu. Rasulullah menyuruh umatnya untuk menggunakan akal dalam memperhatikan alam dan fenomena sekitar. Dalam menjelaskan keesaan Allah, beliau menyuruh umatnya untuk mentadabburi alam. Dengan melihat keteraturan fenomena alam, pergantian siang dan malam dan hukum-hukum alam lain di dunia ini, beliau mengenalkan Allah kepada umatnya. Dzat yang mengatur segala sesuatu di dunia ini haruslah kuat, dan mampu atas segalanya. Dia juga harus mengetahui segala ssuatu dan bijak. Dzat tersebut juga haruslah berbeda dengan apa saja yang ada di dunia, termasuk manusia. Dzat tersebut juga pastinya tidak membutuhkan alam, sedangkan alam termasuk di dalmnya manusia pasti membutuhkan-Nya. Salah satu ayat yang menjelaskan tentang perintah penggunaan akal dalam memperhatikan fenomena yang ada di dunia adalah /wa fi anfusikum afalaa tubsirun/ dan /falyandzuri al-insan mimma khuliq, khuliqa min main dafiq, yakhruju min baini sulbi wa taraib/. Adapun sedikit penyampaian tentang mukjizat dan kabar mengenai hal yang gaib diperuntuhkan untuk orang-orang yang fanatik terhadap paham tertentu yang menginginkan penghinaan 
(menantang) terhadap mukjizat. Prinsip kedua adalah dengan gaya atau uslub yang bijak. Rasulullah merupakan manusia yang bijaksana. Dalam menasehati kaumnya beliau menggunakan dua gaya penyampaian, yakni ijaz dan itnab. Ijaz sebagaimana yang tertera di dalam setiap surat yang beliau kirim kepada para raja, yang suratnya mengedepankan penjelasan yang singkat padat. Sedangkan itnab digunakan oleh Rasulullah ketika menjelaskan hukum, memotivasi sebelum melakukan peperangan, dan menasehati setiap jiwa agar memperindah akhlak. Beliau dengan panjang lebar menjelaskan hal-hal tersebut kepada kaumnya. Selain itu beliau juga sering memberikan permisalan degan sesuatu yang nyata dan ada. Prinsip ketiga adalah dengan adab atau akhlak yang tinggi. Nabi Muhammad merupakan panutan atau uswah hasanah bagi para pengikutnya. Beliau merupakan pendakwah dengan akhlak dan perilakunya yang sangat baik sebelum benar-benar menjadi pendakwah. Ini adalah cara tertinggi dalam berdakwah dan upaya menyebarkan agama Islam, yakni dengan melakukan perbuatan baik dan berakhlak baik, sehingga orang-orang di sekitarnya akan terpengaruh dan mengikuti kebaikan yang dilakukannya. Prinsip keempat adalah dakwah dengan politik yang bijak. Dengan politik yang bijak Nabi Muhammad berhasil dalam melakukan dakwahnya. Dalam melakukan dakwah dengan memberikan nasehat-nashat yang baik beliau sangat memperhatikan waktu para audiennya. Sehingga audien benar-benar mendengarkannya dan tidak merasa terbebani untuk mendengarkannya. Beliau mencari waktu luang dalam menyampaikan dakwah. Selanjutnya adalah beliau melakukan sesuatu yang masih trend di masa itu dengan tujuan dakwah. Beliau memiliki cincin yang tertulis di dalamnya /Muhammadu Rasulullah/. Cincin tersebut digunakan juga untuk cap surat. 
Hal tersebut dikarenakan para raja tidak mau membaca surat jika tidak ada cap cincin di dalam surat yang dikirim untuknya. ${ }^{30}$ Selain itu muammalah (pergaulan) yang baik merupakan hal terpenting dalam dakwah. ${ }^{31}$

\section{e. Pengertian al-wa'dzu wa irsyad}

Untuk terminologi yang pertama, yakni $a l$-wadzu harus diperhatikan dua kata lainnya yang berkaitan yaitu tadzkir dan qasas. Untuk kata alwa'dzu atau mauidzah atau idzzah adalah nasehat (an-nushu). Adapun tadzkir adalah upaya untuk mengingatkan akibat-akibat dari sebab, baik akibat baik atau akibat buruk dari perbuatan manusia. Menurut Ibnu Saydih tadzkir adalah upaya untuk melembutkan hati seseorang dengan menjelaskan pahala dan hukuman. Tadzkir juga bisa diterjemahkan dengan perkataan yang benar dapat melembutkan hati dan mempengaruhi jiwa sehingga jiwa dapat lebih bersih dan mendapatkan iman dan hidayah. Adapun yang kedua adalah qasas atau kisaah. Dalam melakukan al-wa'dzu unsur qasas juga sangat berperan. Seseorang yang bercerita atau al-qassaas atau al-qas sangat identik atau diidentikan dengan waa 'idz yaitu orang yeng memberi nasehat karena melakukan upaya nasehat dengan menceritakan kisah-kisah lampau yang memiliki ibrah atau pelajaran. Di dalam menyampaikan kisah, seorang pendakwah harus mengaitkannya dengan kisah-kisah yang ada di dalam Alquran, hadits dan atsar sahabat. Adapun kisah-kisah israiliyyat, Ali Mahfudz membaginya menjadi tiga, yakni israiliyyat yang diterima tanpa keraguan sedikitpun karena tidak bertentangan dengan Alquran dan al-Sunnah, (2) israiliyyat yang ditolak sama sekali tanpa keraguan karena bertentangan dengan keduanya dan tidak

\footnotetext{
${ }^{30}$ Mahfudz, 34.

${ }^{31}$ Mahfudz, 42.
} 
diterima akal, dan (3) israiliyyat yang belum diketahui kebenarannya. Sehingga seorang da'i harus melakukan kajian yang mendalam terhadap kisah tersebut sebelum dijadikan sebagai materi nasehat dan mauidzah. ${ }^{32}$

Sedangkan termnologi al-Irsyad merujuk pada petunjuk (hidayah) ke jalan yang diinginkan, yakni mendapatkan petunjuk dan istiqamah di atas jalan kebenaran dan tetap di dalam jalan tersebut. Secara umum dapat dikatakan bahwa al-wa'dzu merupakan nasehat dan pengingat akan kebaikan dan kebenaran yang diterima oleh hati dan diejawantahkan melalui amalan. Sedangkan al-irsyad adalah motivasi, perintah, atau anjuran untuk melakukan kebaikan dan menjauhi keburukan dengan cara memberi ancaman dan iming-iming kebaikan. Tujuan dari keduanya adalah memperbaiki sendi kehidupan manusia dan kemenangan untuk mendapatkan kebahagiaan, baik di dunia maupun di akhirat kelak.

Adapun keutamaan atau kemuliaan $a l$-wa'dzu dan al-irsyad adalah (1) keduanya merupakan tugas para nabi, rasul dan para pengikut mereka seperti para ulama, mujahidin, dan para umara yang adil. (2) keduanya berkaitan dengan suatu hal yang sangat esensial di dalam kehidupan, yakni jiwa, (3) tujuan keduanya adalah kebahagiaan hidup dengan menghiasi diri dengan kebaikan dan mengosongkan diri dari perbuatan buruk sehingga mendapatkan kebahagiaan dan kemenangan abadi. ${ }^{33}$

Menurut Ali Mahfudz, hati manusia itu sama halnya dengan anggota badan lainnya. Anggota badan lain bisa terkena penyakit dan jika tidak diobati maka penyakit tersebut akan semakin mengkhawatirkan. Cahaya di dalam hati bisa saja redup atau bahkan hilang karena terkena penyakit

\footnotetext{
${ }^{32}$ Mahfudz, 82.

${ }^{33}$ Mahfudz, 73.
} 


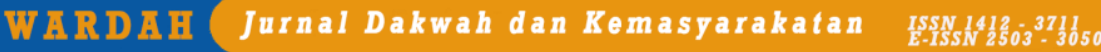

kesesatan. Kesesatan akan menimbulkan munculnya penyakit seperti terjerumusnya syahwat, melakukan larangan-larangan agama, tidak mempedulkan kefasikan dan dosa, menikmati keburukan bid'ah, meninggalkan atau mencampakkan akhlak yang baik sesuai dengan tuntunan agama, dan melakukan dosa yang tidak diridhoi oleh syara' dan akal sehat manusia. Adapun obat satu-satunya untuk penyakit tersebut adalah dengan adanya mau'idzah, isyad dan nasehat-nasehat yang dilandaskan pada Alquran dan al-Sunnah. ${ }^{34}$

\section{f. Adab pendakwah}

Sebagaimana yang telah diketahui bahwa dakwah sejatinya merupakan pekerjaan dan tugas para nabi. Sedangkan para ulama adalah perwakilan dan suksesor mereka dalam menjaga syariat, agama, dan yang menghidupkannya. Oleh karena itu, para da'i atau pendakwah memiliki keistimewaan berupa mengesakan Allah dan mengetahuinya-Nya, mengamalkan kebaikan dan mengajak orang lain untuk melakukan hal yang sama. Menurut Ali Mahfudz mereka berada di tingkatan orang yang alim, amil yang mengajak manusia menuju Allah, mereka memiliki hati yang hidup, keimanan yang sungguh-sungguh, dan keikhlasan yang benar.

Untuk itu ada beberapa adab yang harus dimiliki oleh seorang pendakwah, di antaranya adalah (1) seorang pendakwah harus mengetahui dan memahami Alquran, al-Sunnah, sejarah para nabi dan para sahabat nabi. Dengan begitu bereka juga dituntut untuk memiliki pengetahuan yang cukup mengenai hukum dan rahasia-rahasia syariat Islam. Ali Mahfudz juga mengutip salah satu hadits yang berbunyi /man suila fa afta bigairi 'ilmin faqad dzalla wa azalla/ 'barang siapa ditanya seseorang mengenai 
suatu hukum dan dia berfatwa tanpa dilandaskan pada ilmu, maka dia telah sesat dan menyesatkan'. (2) mengamalkan ilmu yang telah dimiliki. Seorang pendakwah harus melakukan terlebih dahulu apa yang telah diketahuinya. Mereka juga terlebih dahulu meninggalkan suatu yang diharamkan sebelum melakukan pelarangan kepada orang lain. (3) kesabaran dan lapang dada. Seorang pendakwah harus memiliki kesabaran dan kelapangan dada. Sehingga kesempurnaan ilmu yang terpancar dari kesabaran, kelembutan perkataan menjadi kunci hati yang dapat mengobati segala penyakit jiwa. Orang yang memiliki kesabaran dan kelapangan dada akan menjadi pribadi yang tenang, dan hati yang tentram tidak akan dikalahkan oleh kemarahan dan kedengkian. Hal tersebut telah terpatri di dalam Alquran untuk imam para da'i Nabi Muhammad saw, /wa lau kunta faddzan ghalidza al-qalbi lanfaddzu min haulik/. (4) memiliki keberanian dalam membela dan menyampaikan kebenaran. Sehingga orang yang pengecut, memiliki hati yang lemah, sehingga tidak memiliki keberanian dalam membela kebenaran, mengubah kemunkaran, maka orang-orang tersebut tidak pantas menjadi pemimpin umat dan dokter rohani. ${ }^{35}$ (5) menjadi pemaaf dan tidak mempedulikan harta yang diberikan oleh manusia karena dakwahnya. Menurut Ali Mahfudz seorang pendakwah jangan sampai seperti penjual agama. Beliau mengutip perkataan Abu Said al-Hasan al-Bisry mengatakan bahwa "seorang laki-laki akan tetap mulia sampai dia rakus terhadap uang rakyat, jika sampai dia melakukannya, maka bersembunyilah darinya, bencilah perkataannya dan dirinya sendiri. Dia juga mengutip perkataan masyarakat A'rabi yang berkata kepada penduduk basrah "Siapa sayyid (pemimpin) kalian?, mereka menjawab 
'Hasan', lalu 'Arabi bertanya kembali "Dengan apa dia dapat menguasai (memimpin) kalian?", maka mereka menjawab "Masyarakat membutuhkan ilmunya, sedangan dia tidak membutuhkan dinar mereka" maka "Arabi menimpali "Sungguh ini adalah hal yang sangat baik". ${ }^{36}$ (6) bersifat qana'ah terhadap kehidupan dunia dan ridha dengan apa yang dimiliki, (7) memiliki kemampuan menjelaskan yang baik dan lisan yang fasih, (8) menguasai medan. Ali Mahfudz mengatakan bahwa salah satu sebab kenapa Abu Bakar terpilih menjadi Khalifah dan msyarakat Arab pada saat itu rela akan hal tersebut karena beliau mengetahui seluk beluk bangsa Arab pada saat itu. Beliau mengetahui karakteristik kabilah-kabilah bangsa Arab, sejarah mereka, dan akhlak-akahlak mereka seperti pemberani, pengecut, amanah, khiyanat, lemah, kuat, kaya, dan miskin. ${ }^{37}$ (9) memiliki siat tsiqqah kepada Allah dalam meyakini janjinya dan memiliki harapan yang kuat kepada-Nya untuk mendapatkan kemanfaatan (10) memiliki sifat tawadhu' dan menghindari sifat 'ujub. (11) jangan sampai seorang pendakwah memiliki sifat pelit ilmu dan hitung-hitungan dalam mengajarkan ilmu yang dimiliki. Dia juga dilarang untuk melarang audiennya memanfaatkan apa yang telah diketahui darinya. (12) memiliki kesabaran yang tinggi. Ini adalah sifat para nabi dalam melakukan dakwah, sehingga mereka berhasil dalam melakukan dakwah kepada manusia untuk menuju Allah SWT. (13) mengetahui bahasa umat yang diajdikan objek dakwah. Seorang da'i harus menguasai bahasa umat yang mereka dakwahi agar apa yang disampaikan dapat dipahami dan diikuti. Selain yang telah dijelaskan di atas, seorang pendakwah harus memiliki karakteristik yang

\footnotetext{
${ }^{36}$ Mahfudz, 97.

${ }^{37}$ Mahfudz, 100.
} 
memperindah kepribadiannya seperti wara dengan menjauhi hal-hal yang syubhat. ${ }^{38}$

\section{g. Adab seorang pendakwah dengan para audien}

Banyak sekali adab seorang pendakwah kepada para audien atau pendengarnya. Di antaranya adalah mendemonstrasikan apa yang dia sampaikan. Dalam hal ini mengamalkan apa yang dia sampaikan kepada pendengar, karena praktik lebih fasih daripada penjelasan lisan. Selain itu seorang pendakwah harus memiliki ucapan yang lembut dan bersahaja dalam bergaul atau bermuamalah. Konsep tersebut tertera di dalam Alqura'an /wa jadilhum billati hiya ahsan/. Dalam ayat tersebut seorang pendakwah diharuskan menggunakan cara terbaik dalam melakukan perdebatan yakni dengan cara lembut dan bersahaja. Dengan demikian jelas bahwa seorang pendakwah tidak dipekenankan menggunakan kata-kata yang kasar, menghujat, dan lain sebagainya. Dengan perkataan dan perdebatan yang lembut lagi bersahaja, diharapkan hati orang yang mendengarkan akan menjadi lembut, kegelisahan mereka menjadi tenang, dan watak mereka menjadi dinamis dapat diubah. Seorang pendakwah juga harus pandai dalam memuji seseorang, mengingatkannya selalu kepada kebaikan dan mensifatinya dengan sifat-sifat yang baik. Selain itu seorang pendakwah juga harus mampu menghidupkan pada diri lawan bicaranya kemualiaan yang tersimpan dalam diri mereka, sehingga mereka akan dengan mudah menerima nasehat dan dapat mengalahkan hawa nafsu di dalam dirinya.

\section{h. Segala sesuatu yang harus dihindari oleh mursyid}

\footnotetext{
${ }^{38}$ Mahfudz, 111.
} 
Menurut Ali Mahfudz ada beberapa hal yang harus dihindari oleh mursyid. Di antaranya adalah (1) seorang mursyid harus meyakini segala sesuatu yang ada pada Alquran dan al-Sunnah, khususnya mengenai akidah. Seorang pndakwah dianjurkan untuk tidak terlalu dalam memikirkan halhal yang merujuk pada sifat Tuhan yang tidak dijelaskan oleh Rasulullah. Seorang muslim harus meyakini sifat-sifat Allah melalui Alquran dan hadits tanpa meragukannya. Sedangkan jika tetap ragu maka dia harus mempelajari dalil-dalil yang disampaikan oleh para teolog (mutakallimin) dengan kritis sehingga keraguannya akan hilang. Beberapa hal yang harus diyakini oleh seorang pendakwah adalah melakukan tanzih, yakni meyakini bahwa Allah tidak bisa disetarakan atau tidak bisa dibandingkan dengan makhluk-makhluknya. Mengingat bahwa Allah berfirman di dalam Alquran /laisa kamitslihi syai'/ atau/subhana rabbika rabbi izzati 'amma yasifun/. Dengan demikian tujuan Allah menurunkan ayat-ayat mutasyabihat menurut Ali Mahfudz adalah menginginkan adanya kebermanfaatan untuk akhlak, amal, dan keadaan manusia. Sehingga dengan memperhatikan ayat yang membuat manusia mengkhayal seperti /ar-Rahman 'ala al-Arsy istawa/, manusia harus mempercayainya tanpa harus mengetahui caranya seperti apa. Karena manusia tidak mengetahui bagaimana cara yang tidak pernah mereka lihat sebelumnya. Adapun cara kedua adalah menta'wilkannya dengan makna majazi. Sehingga ayat tersebut tidak dimaknai secara tekstual, tetapi dengan akal, manusia dapat menghubungkan dengan makna kedua yang dapat diterima akal dan tidak bertentangan dengan nash lain.

Adapun hal lain yang harus dihindari adalah berbicara kepada orang awwam mengenai hal yang tidak dapat dipahami dan diterima. Karena bisa 
jadi audien akan mengalami salah paham sehingga akan melakukan perbuatan atau amalan yang tidak sesuai dengan apa yang dinginkan oleh pendakwah. ${ }^{39}$ Selain itu pendakwah juga dilarang memaknai terminologi hukum dengan makna bathin yang mana di dalam lafadz tersebut tidak mengandung indikasi makna bathin. Seperti lafadz shalat, zakat, haji dan sebagainya. Kebanyakan yang melakukan hal tersebut adalah ahli bathin yang mengatakan bahwa apa saja yang ada di dalam Alquran dan al-Sunnah memiliki dua makna, yakni dzahir dan bathin. Dengan bersikap terlalu ekstrim dalam hal ini, maka mereka cenderug meninggalkan kewajiban shalat, zakat dan rukun Islam lainnya. Ali Mahfudz mencotohkan jama'ah Ahmadiyah yang dipimpin oleh Mirza Ghulam Ahmad yang dianggap sebagai al-masih yang diterangkan di dalam hadits-hadits. Dia juga dianggap mendapatkan wahyu sehingga menghilangkan atau menghapus kewajiban jihad dan membela agama dan Negara.

\section{i. Khitabah "khutbah"}

Selain istilah wa'dzu dan irsyad yang melekat pada konsep dakwah dan pendakwah ada istilah lain yang dijelaskan oleh Ali Mahfudz, yakni khitabah atau ceramah dalam bahasa Indonesia. Secara bahasa khitabah atau khitab merupakan masdar khataba-yakhtubu yang bermakna menyampaikan pembicaraan untuk orang lain dalam rangka memahamkan suatu informasi atau ilmu. ${ }^{40}$ Adapun menurut para hukama (orang-orang bijak) khitabah adalah kumpulan hukum atau kaidah dalam meyakinkan (iqna') sejauh mungkin seseorang, terhadap suatu informasi atau ilmu.

\footnotetext{
${ }^{39}$ Mahfudz, 126.

${ }^{40}$ Ali Mahfudz, Fan Khitabah Wa I'dadu Al-Khatib (Qahirah: Dar I'tisam, tanpa tahun), 12.
} 
Iqna' di sini bermakna mempengaruhi pendengar sehingga dapat menerima kebenaran ucapan yang disampaikan baik untuk melakukan suatu perbuatan atau untuk meninggalkannya. Secara garis besar, khutbah ada dua macam, pertama adalah burhani, yakni menyampaikan suatu hal dengan bukti-bukti logis yang dibangun atas bukti ilmiah, ketika akal mampu menerima apa yang disampaikan dan kedua adalah khitaby yakni menerimanya akal dengan perkataan seorang khatib yang didasarkan para kiasan atau perumpamaan yang dilandaskan pada sumber yang kuat dan dilandaskan pada keyakinan-keyakinan yang dibenarkan oleh masyarakat umum (bayani dan irfani).

Adapun para filsuf mengartikan khitabah sebagai ilmu yang memiliki dasar dan hukum yang dapat dipelajari untuk mempengaruhi orang lain dengan ucapan. Selain itu dalam ilmu khitabah akan ditemukan media yang dapat meyakinkan seseorang dengan tujuan-tujuan tertentu. Dengan demikian seorang khatib atau penceramah harus memiliki sifat dan adab yang baik, menguasai kecenderungan audien dan mengetahui gaya atau model-model dalam berkhutbah. Sehingga khutbah adalah kepemilikan kemampuan dalam meyakinkan menarik dan membawa hati audien dalam menerima apa yang disampaikan. Perlu diketahui juga bahwa menurut Ali Mahfudz khitabah dan muhadarah memiliki perbedaan. Meskipun pada saat ini (ketika buku Fann Khitabah ditulis) banyak sekali yang meyakini bahwa mukhadarah merupakan sinonim dari khitabah. Mukhadarah merupakan kegiatan di mana seseorang menjawab orang lain berdasarkan pada jawaban sebelumnya yang telah disampaikan. Artinya mukkhadarah adalah kegiatan saling jawab dan cenderung masuk dalam ilmu 
kesusatraan. ${ }^{41}$ Menurut penulis, bisa jadi mukhadarah dapat dikiaskan dengan adu pantun bagi orang-orang betawi yang di dalam pantun tersebut terdapat makna yang mendalam. Di sisi lain, mukhadarah juga dapat dimaknai sebagai acara seminar atau diskusi dua arah. Khutbah juga berbeda dengan munadzarah yang dapat diartikan sebagai perdebatan dua arah yang saling menguatkan argmentasinya untuk mempertahankan keyakinan mereka.

Menurut Ali Mahfudz khutbah bermacam-macam. Di antaranya adalah khutbah ilmiyyah, khutbah politik, dan khutbah keagamaan. Menurut Ali Mahfudz khutbah ilmiyyah pada awalnya merupakan penyampaian materi di seminar-seminar ilmiah kepada audiens, sebagaimana seorang guru menjelaskan materi kepada murid di depan kelas. Selain itu khutbah ilmiyyah sangat miskin akan retorika dan keindahan balaghah sehingga memberikan sedikit sekali efek pada jiwa pendengar, tidak mengobarkan semangat, kasih sayang dan lain sebagainya. Akan tetapi sesungguhnya, khatib ilmiy dapat keluar dari materi yang kering atau gersang dari "memberikan efek rasa" kepada para audiens dengan suatu pujian, peringatan kematian dengan mengingat kemuliaanya (ta'bin) ucapan syukur, ucapan selamat, dan sebagainya. Sehingga materi khutbah yang disampaikan akan terasa indah, sederhana tetapi menimbulkan efek yang luar biasa untuk jiwa dan hati pendengar. Dengan demikian, Ali Mahfudz membuat suatu definisi Khitab al-Madh yang diartikan sebagai pujian terhadap suatu yang mulia atau sososk yang memiliki kemuliaan dan anugrah. Adapun sebab dari pujiannya tidak keluar dari keutamaankeutamaan jiwa. Dengan demikian seorang khatib menceritakan sososok

${ }^{41}$ Mahfudz, 14. 
yang dipuji berdasarkan akhlak yang mulia, rasa dan jiwa mulia yang dimiliki dengan memberikan bukti-bukti nyata akan pengaruh sosok yang dipuji dan karya-karyanya tersebut untuk segenap manusia.

Untuk itu ada langkah-langkah yang harus diperhatikan dalam penyajian khutbah ilmiyyah. Pertama, khutbah harus dibuka dengan menyebutkan keutamaan-keutamaan yang sesuai dengan sosok atau objek yang dipuji sebagai model dan menjelaskan pengaruhnya terhadap masyarakat luas. Kedua menjelaskan keadaan-keadaan masyarakat sebelum kehadiran atau kemunculan sosok yang dipuji tersebut. Keadaan atau kondisi yang perlu dijelaskan adalah kondisi keagamaan, keilmuan, akhlak, dan politik. Setelah itu baru menjelaskan apa yang terjadi setelah sosok atau tokoh yang dipuji masuk ke dalam masyarakat. Contohnya adalah menjelaskan keadaan masyarakat Bani Israil di Mesir sebelum Nabi Musa datang dengan menggambarkan kesewenang-wenangan Firaun yang memperbudak mereka. Sehingga ketika Nabi Musa datang, Bani Israil dapat terlepas dari belenggu perbudakan. Selain itu sejarah tentang keadaan masyarakat Arab sebelum Nabi Muhammad dilahirkan sehingga menjadi Nabi dan Rasul juga dapat dijadikan contoh. Dengan datangnya Nabi Muhammad maka msyarakat Arab dapat merasakan hidayah dengan meninggalkan peribadatan kepada patung. Ketiga, seorang khatib harus menyampaikan nilai-nilai kemuliaan jiwa yang ada pada model yang diterangkan dengan sederhana tanpa adanya unsur melebih-lebihkan. Nilainilai yang disampaikan adalah kebijaksanaan, keberanian, lapang dada, adil, kedermawanan, memiliki semangat yang tinggi, memiliki sifat lemah lembut, memiliki kasih sayang untuk orang-orang yang lemah, dan lain sebagainya. Keempat, menyampaikan ilmu-ilmu dan karya-karyanya 
bermanfaat kepada para audiens. Kelima, jika memang yang dipuji berasal dari keluarga yang memiliki nasab yang baik, maka hal tersebut juga dapat disampaikan. terlebih jika pendahulunya juga memiliki pengaruh yang sangat baik dan cukup besar bagi masyarakat luas. Keenam, menjelaskan tentang daerah atau negara di mana dia lahir, tumbuh dan berkembang. ${ }^{42}$

Konsep dakwah nir-radikalisme juga sangat terlihat di dalam metode dakwah politik yang dijelaskan oleh Ali Mahfudz. Menurutnya, khutbah politik merupakan khutbah yang paing sulit, karena harus "mendamaikan" antara pemerintah dan masyarakat. Seorang khatib harus mengetahui isi undang-undang suatu negara. Sehingga materi dakwah atau materi khutbah di depan para petinggi negara seperti presiden, mentri, DPR, dan lain sebagainya dapat diterima. Di sisi lain, materi khutbah juga harus memihak rakyat secara umum untuk kemaslahatan bernegara. Untuk itu dalam khutbah politik ada beberapa yang harus diperhatikan, (1) mengetahui undang-undang atau hukum suatu negara, sehingga seorang khatib mengetahui hak-hak masyarakat dan dapat memberikan masukan akan kebijakan pemerintah, baik untuk dalam negeri maupun kebijakan luar negeri. (2) dakwah atau khutbah harus murni karena cinta negara, dan dimaksudkan untuk kebaikan umat secara umum, (3) harus independen, tidak menyampaikan pendapat "titipan" dari penguasa. ${ }^{43}$

Adapun khutbah keagamaan, sudah dicontohkan oleh Nabi Muhammad saw yang juga diteruskan oleh para khulafau rasyidin dan generasi setelahnya. Di dalam melakukan khutbah Rasulullah menyeru manusia untuk beriman kepada Allah, masuk ke dalam Agama Allah, dan

\footnotetext{
${ }^{42}$ Mahfudz, 72.

${ }^{43}$ Mahfudz, 83.
} 
memperbaiki akhlak manusia. Hal tersebut tidak mengherankan karena tujuan dari khutbah keagamaan adalah mengajak manusia untuk menuju huda atau petunjuk, mengobati penyakit hati, menuju kemuliaan, dan memperbaiki akhlak atau budi pekerti manusia. Di dalam melakukan khutbah keagamaan, seorang khatib harus menjelaskan tema tertentu, dan menganalisisnya melalui naskah agama, sosial, dan moral yang ada pada masyarakat.

\section{Kesimpulan}

Konsep dakwah nir radikalisme yang disampaikan oleh Ali Mahfudz terejawantahkan melalui tiga konsepsi besar, yakni mauidzah (tadzkir dan qissah), isryad, dan khitabah yang di dalamnya terdapat repitisi penjelasan tentang pentingnya lemah lembut, bijaksana, lapang dada, sabar, dan selalui mengikuti cara dakwah rasul di dalam Alquran yang meliputi hikmah, mauidzah hasanah, dan perdebatan dengan cara yang paling baik. Di sisi lain seorang pendakwah harus menampilkan argumentasi kuat dengan penggunaan akal sehat di dalam aktifitas dakwah. Dalam hal ini, Ali Mahfudz bersikap tawazun dalam penggunaan nash agama (wahyu) dan potensi akal manusia. Selain itu di dalam hal yang bersifat khilafiyah, beliau hanya sekedar memaparkan saja, tanpa memaksa pembaca untuk fanatik terhadap satu paham, seprti hukum bagi seseorang yang tidak mendapatkan dakwah yang didasarkan pada paham muktazilah, Asy'ariyah, dan al-Maturidiyah dan penggunaan israiliyyat sebagai materi dakwah. Beliau juga memperbolehkan penggunaan takwil dalam memaknai ayat mutasyabihat, tidak tekstualis dan anjuran untuk merujuk para pakar teologi (mutakallimin) sebagai upaya mengenal sifat Allah SWT lebih 
dalam. Selain itu dari sejarah biografinya ditemukan bahwa beliau pada awalnya bermadzhab syafi'i, mengikuti madzhab yang digunakan oleh keluarga besarnya, kemudian ketika melanjutkan studi di al-Azhar asSyarif, beliau mengamalkan fiqih madzhab Hanafi. Hal ini menunjukkan bahwa beliau bukanlah seorang yang fanatik dalam bermadzhab. Berdasarkan data tersebut, peneliti tidak menemukan kesesuaian indikator radikal dalam konsep dakwah Ali Mahfudz sebagaimana yang disampaikan oleh Yusuf Alqardawi yang meliputi fanatisime madzhab dan pendapat, mewajibkan sesuatu padahal Allah SWT tidak mewajibkan hal tersebut, menerapkan ajaran Islam dengan keras di tempat yang tidak seharusnya, dan mempraktikkan sikap keras dalam bergaul dan berdakwah.

\section{Referensi}

Amin, Samsul Munir. (2014). Sejarah dakwah.

Anas, Ahmad, and Abu Fina. (2006). Paradigma dakwah kontemporer: aplikasi teoritis dan praktis dakwah sebagai solusi problematika kekinian. Semarang: Pustaka Rizki Putra.

Asror, Ahidul. (2018). Paradigma dakwah konsepsi dan dasar pengembangan ilmu. Yogyakarta: LKiS Yogyakarta. http://digilib.iain-jember.ac.id/253/.

Aziz, H. Moh Ali. (2004). Ilmu Dakwah. Jakarta: Kencana.

Anonim. (2019). "DAKWAH DAN PENGEMBANGAN

MASYARAKAT.” Accessed December 13, 2019.

http://altajdidstain.blogspot.com/2011/02/dakwah-danpengembangan-masyarakat.html.

Mahfudz, Ali. Fan Khitabah Wa I'dadu Al-Khatib. Qahirah: Dar I'tisam, tanpa tahun. 
Mahsun, M. S. (2005) Metode penelitian bahasa: tahapan strategi, metode dan tekniknya. Jakarta: PT RajaGrafindo Persada.

news.detik.com . 2019. "Dipolisikan, Ustaz Maaher: Saya Jelaskan Fikih Bukan Ajak Bunuh Abu Janda." Accessed December 13, 2019. https://news.detik.com/berita/d-4803770/dipolisikan-ustaz-maahersaya-jelaskan-fikih-bukan-ajak-bunuh-abu-janda.

Razzaq, A. (2015). Dinamika Dakwah dan Politik Dalam Pemikiran Islam Modernis di Indonesia. Wardah, 15(1), 7-15. Retrieved from http://jurnal.radenfatah.ac.id/index.php/warda/article/view/202.

Razzaq, A. (2017). Dakwah dan Pemikiran Politik Islam : Kajian Teoritis dan Empiris. Palembang: NoerFikri Publisher.

Razzaq, A., \& Perkasa, J. (2019). Penafsiran Ayat-Ayat Jihad Dalam Kitab Al-Qur'an Al-'Adzim Karya Ibnu Katsir. Wardah, 20(1), 71-84. Retrieved from http://jurnal.radenfatah.ac.id/index.php/warda/article/view/3621

Raco, J.R. Metode Penelitian Kualitatif. Jakarta: PT Grasindo, 2010.

Rosidah, Rosidah. "DEFINISI DAKWAH ISLAMIYYAH DITINJAU DARI PERSPEKTIF KONSEP KOMUNIKASI KONVERGENSI KATHERINE MILLER." QATHRUNÂ 2, no. 02 (December 10, 2015): 155-78.

suara.com. (2019). "Laporkan Balik Abu Janda, Ustaz Maheer: Dia yang Ketakutan," December 1, 2019. https://www.suara.com/news/2019/12/01/185425/laporkan-balikabu-janda-ustaz-maheer-dia-yang-ketakutan.

. (1979). Hidayatul Mursyidin Ila Turuqi Al-Wa'dzi Wa AlKhitabah. Qahirah: Dar I’tisam, 1979. 
tribunnews.com. (2019). "Klarifikasi Gus Muwafiq Soal Masa Kecil Nabi Muhammad SAW, Budiman Sudjatmiko Minta Tak Diperpanjang Tribunnews.Com." Accessed December 13, 2019. https://www.tribunnews.com/nasional/2019/12/03/klarifikasi-gusmuwafiq-soal-masa-kecil-nabi-muhammad-saw-budimansudjatmiko-minta-tak-diperpanjang.

UIN Sunan Gunung Djati, ed. (2014). Kajian Dakwah Multiperspektif:

Teori, Metodologi, Problem, Dan Aplikasi. Cetakan pertama. Bandung: Kerja sama Fakultas Dakwah dan Komunikasi, Universitas Islam Negeri Sunan Gunung Djati dan PT Remaja Rosdakarya. 